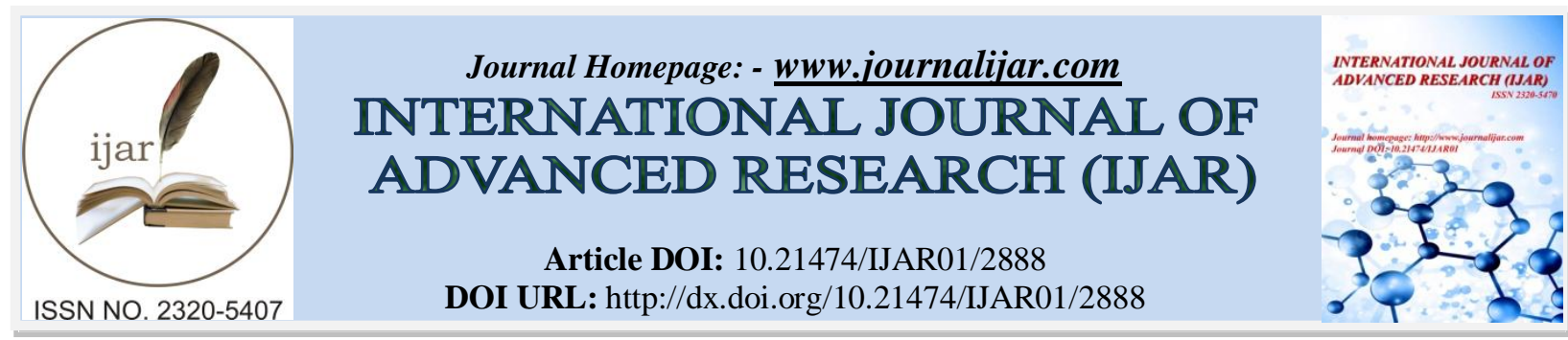

RESEARCH ARTICLE

\title{
"COMPARATIVE EVALUATION OF ETOMIDATE AND THIOPENTONE SODIUM WITH ROCURONIUM FOR RAPID SEQUENCE INTUBATION IN PREGNANT PATIENTS UNDERGOING LOWER SEGMENT CAESEREAN SECTION (LSCS)” A COMPARATIVE STUDY.
}

Dr. Mayank Agrey, Dr. Omprakash Sundrani, Dr. Santosh Tharwani and Dr. Jaya Lalwani.

\section{Manuscript Info}

Manuscript History

Received: $x x x x x x x x x x x x x x x$

Final Accepted: $x x x x x x x x x x x$

Published: $x x x x x x x x x x x x x x x$

Key words:-

Intubating conditions, Rocuronium,

Etomidate, Thiopentone Sodium.

\begin{abstract}
The aim of this study was to compare the intubating conditions and haemodynamic response for rapid sequence intubation (RSI) of the induction agents, etomidate and thiopentone sodium, with a rapid acting neuromuscular blocking agent rocuronium in 100 ASA grade I-II patients of age 20-40 yrs, undergoing lower segment caesarean section. All the patients were divided in a randomized double blind fashion into two groups of 50 patients each. Group I patients received Etomidate $(0.3 \mathrm{mg} / \mathrm{kg}$ ) with Rocuronium $0.9 \mathrm{mg} / \mathrm{kg}$ and intubated at 90 seconds, group II patients received Thiopentone sodium $(5-7 \mathrm{mg} / \mathrm{kg}$ ) with rocuronium bromide $0.9 \mathrm{mg} / \mathrm{kg}$ and intubated at 90 seconds respectively. We observed intubating conditions in group I \& group II, excellent intubating conditions were rated in $82 \%$ \& $96 \%$ and good in $18 \%$ and $4 \%$, respectively. The difference in intubating conditions of patients in both the groups was statistically significant ( $\mathrm{p}$ value $<0.05$ ). Clinically acceptable intubation conditions (excellent \& good) were observed in $100 \%$ patients in both the groups, hence the difference being statistically non significant. There was no significant change in pulse rate and mean systolic blood pressure, diastolic blood pressure, mean arterial pressure from the baseline value after the administration of muscle relaxants in either of the two groups. We conclude that both the induction agents; Etomidate \& Thiopentone sodium in combination with Rocuronium were comparable in terms of intubating conditions \& haemodynamic response. Thus it could be concluded that either of them could be used for rapid sequence intubation in pregnant patients undergoing lower segment Caeserean section (LSCS).
\end{abstract}

Copy Right, IJAR, 2016,. All rights reserved.

\section{Introduction:-}

Obstetric anaesthesiologists face the unique situation of providing anaesthesia for caesarean sections, where they have to provide care for both the mother and the unborn baby. ${ }^{29}$

Obstretics patients undergoing caesarean section under general anaesthesia require rapid sequence induction and intubation (RSII) due to the high risk of aspiration. High rates of caesarean section surgeries are encountered by anaesthesiologists now a days. Despite the popularity of central neuraxial blockade, general anaesthesia may have to be offered to these patients at times because of their choice or conditions. ${ }^{29}$ 
Pulmonary aspiration is one of the concerns of general anaesthesia in obstetric patients. Risk factors for increased risk of aspiration include a prolonged gastric emptying time in labour, increased intra-abdominal pressure due to the gravid uterus and relaxation of the lower oesophageal sphincter due to hormonal changes. To reduce this risk, prophylaxis against acid aspiration is administered prior to anaesthesia. The use of rapid sequence induction with thiopental and succinylcholine has remained standard and largely unchanged for the last four to five decades and was developed to decrease the incidence of pulmonary aspiration. ${ }^{9}$

Rapid sequence induction and intubation (RSII) is an anaesthesia induction technique designed to facilitate rapid tracheal intubation in patients at high risk of aspiration. The main objective of the technique is to minimize the time interval between loss of protective airway reflexes and tracheal intubation with a cuffed endotracheal tube. Because the airway is unprotected during this time, it is the most critical period during which aspiration of gastric contents is likely to occur. ${ }^{29}$

The depolarizing neuromuscular blocking agent, succinylcholine has been the drug of choice for rapid sequence induction and intubation (RSII) and anticipated difficult intubations for its short and rapid acting properties. Nothing had yet replaced succinylcholine in the scenarios of difficult intubation before yet, with advent of Rocuronium antagoinist (ORG-25969, sugamedax) that chelates the drug and act as the reversal agent, Rocuronium can also be used in difficult intubation situations in RSII. Rocuronium may provide an alternative to Succinylcholine when it is contraindicated in conditions, such as hyperpyrexia, hyperkalemia or known family history of abnormal cholinesterase enzyme activity. Rocuronium does not cross placenta, therefore can safely be used in obstretical surgeries where risk of regurgitation requires rapid sequence induction.

The purpose of the present study was to compare the effects on intubation conditions and haemodynamic response for rapid sequence intubation (RSI) of the two well proven but different anaesthetic induction agents, etomidate and thiopentone sodium, with a rapid acting neuromuscular blocking agent rocuronium in patients undergoing caesarean section. ${ }^{9}$

\section{Methods:-}

After obtaining institutional ethical committee clearance and informed written consent for surgery and general anaesthesia. 100 pregnant females of age 20-40 yrs, (ASA) grade I and II undergoing LSCS were selected for the study. All patients underwent a thorough pre-anaesthetic checkup. Patients with known sensitivity to drugs, systemic dysfunction, patient refusal, pre-eclampsia, eclampsia were not included in the study.

The patients were divided into two groups in randomized double blind fashion. Etomidate $(0.3 \mathrm{mg} / \mathrm{kg}) \mathrm{with}$ Rocuronium $(0.9 \mathrm{mg} / \mathrm{kg}$ ) (Group I, $\mathrm{n}=50)$ and Thiopentone $(5-7 \mathrm{gm} / \mathrm{kg}$ ) with Rocuronium $(0.9 \mathrm{mg} / \mathrm{kg}$ ) (Group II, $\mathrm{n}=50$ ). Each group had 50 patients.

All patients were evaluated and examined thoroughly with regards to history, physical examination and investigations. After taking written and informed consent, patients were shifted to operation theatre. Intravenous line was maintained by inserting $18 \mathrm{G}$ i.v. cannula in dorsum of hand. Patients were premedicated with inj. Ranitidine 50 $\mathrm{mg}$ i.v., inj. Metoclopramide $10 \mathrm{mg}$ i.v., and inj. Pentazocine $0.5 \mathrm{mg} / \mathrm{kg}$. Philips MP 30 multipara monitor was applied to monitor pulse rate, non-invasive blood pressure, ECG, $\mathrm{SpO}_{2}$, and EtCO2.

Pre-oxygenation with $100 \% \mathrm{O}_{2}$ was done. Patients were induced with inj. Thiopentone sodium $5 \mathrm{mg} / \mathrm{kg}$, or inj. Etomidate $0.3 \mathrm{mg} / \mathrm{kg}$ and inj. Rocuronium $0.9 \mathrm{mg} / \mathrm{kg}$. After $90 \mathrm{sec}$., laryngoscopy was done, cricoid pressure was applied during placement of the proper size endotracheal tube and intubation was done. Endotracheal tube was fixed after checking for bilateral air entry. Anaesthesia was maintained with $\mathrm{O}_{2} 50 \%, \mathrm{~N}_{2} \mathrm{O} 50 \%$ and isoflurane and neuromuscular blocker, At the end of surgery, when patient resumed some breathing effort, residual effects of neuromuscular block was reversed with inj. Neostigmine $0.05 \mathrm{mg} / \mathrm{kg}$ and inj. Glycopyrrolate $0.01 \mathrm{mg} / \mathrm{kg}$. When the patient became fully awake, the patient was extubated after proper oral suction and oxygenation.

The following parameters were monitored at pre operative (baseline), after premedication, after induction at every 1 min. for $5 \mathrm{~min}$., every $5 \mathrm{~min}$. for $15 \mathrm{~min}$ and thereafter at every $15 \mathrm{~min}$. till the end of procedure:-Heart rate (HR), Systolic blood pressure (SBP), Diastolic blood pressure (DBP), Mean blood pressure (MBP), Oxygen saturation (SpO2), End-tidal Carbon dioxide $\left(\mathrm{EtCO}_{2}\right)$, Respiratory rate $(\mathrm{RR})$, ease of laryngoscopy and intubating conditions were assessed using the criteria of Cooper \& Colleagues. 


\section{Scoring Condition for Intubating condition (given by Cooper and Colleagues)}

\begin{tabular}{|c|c|c|c|}
\hline SCORE & $\begin{array}{l}\text { JAW } \\
\text { RELAXATION } \\
\text { (LARYNGOSCOP } \\
\text { Y) }\end{array}$ & VOCAL CORDS & $\begin{array}{l}\text { RESPONSE TO } \\
\text { INTUBATION }\end{array}$ \\
\hline O. & $\begin{array}{l}\text { POOR } \\
\text { (IMPOSSIBLE) }\end{array}$ & CLOSED & $\begin{array}{l}\text { SEVERE COUGHING } \\
\text { AND BUCKING }\end{array}$ \\
\hline 1. & $\begin{array}{l}\text { MINIMAL } \\
\text { (DIFFICULT) }\end{array}$ & CLOSING & MILD COUGHING \\
\hline 2. & $\begin{array}{l}\text { MODERATE } \\
\text { (FAIR) }\end{array}$ & MOVING & $\begin{array}{l}\text { SLIGHT } \\
\text { DIAPHRAGMATIC } \\
\text { MOVEMENT }\end{array}$ \\
\hline 3. & $\begin{array}{l}\text { GOOD } \\
\text { (EASY) }\end{array}$ & OPEN & NONE \\
\hline $\begin{array}{l}\text { 8-9 } \\
=\text { EXCELLENT }\end{array}$ & $6-7=$ GOOD & $3-5=F A I R$ & $0-2=$ POOR \\
\hline
\end{tabular}

Excellent and good intubating conditions were considered clinically acceptable: - All the observation were recorded, tabulated, and analyzed with SPSS (version 13.0, SPSS Inc., Chicago, IL) statistical software. Demographic data, systolic blood pressure, diastolic blood pressure, mean blood pressure, heart rate, respiratory rate, $\mathrm{EtCO} 2, \mathrm{SpO} 2$, condition of vocal cords and response to intubation data were compared between both the groups using unpaired student t-test. For intubating conditions, Chi-square test was used. The quantitative data were expressed as mean (standard deviation). A p-value less than 0.05 were considered significant.

On the basis of results obtained \& statistical evaluation, inference was drawn.

\section{Results:-}

All the two groups were comparable to each other in terms of age, weight, gravida, parity and ASA grading.

\begin{tabular}{|c|c|c|}
\hline \multicolumn{3}{|c|}{ TABLE-1 DEMOGRPHIC DATA } \\
\hline & $\begin{array}{c}\text { GROUP I } \\
(\mathbf{n = 5 0 )}\end{array}$ & $\begin{array}{c}\text { GROUP II } \\
(\mathbf{n}=\mathbf{5 0})\end{array}$ \\
\hline AGE & $25.07 \pm 3.50$ & $25.36 \pm 3.46$ \\
\hline WEIGHT & $59.39 \pm 3.14$ & $50.79 \pm 2.60$ \\
\hline
\end{tabular}

On comparison of intubating conditions in group I \& group II, excellent intubating conditions were rated in $82 \%$ \& $96 \%$ and good in $18 \%$ and $4 \%$, respectively. The difference in intubating conditions of patients in both the groups was statistically significant ( $\mathrm{p}$ value $<0.05$ ). More excellent intubating conditions were observed in group II compare to group I. (Table-2). Clinically acceptable intubation conditions (excellent \& good) were observed in $100 \%$ patients in both the groups, hence the difference being statistically non significant.

Table 2:- Intubating conditions

\begin{tabular}{|c|c|c|c|}
\hline \multirow{2}{*}{$\begin{array}{c}\text { INTUBATING } \\
\text { CONDITION }\end{array}$} & $\begin{array}{c}\text { GROUP I } \\
(\mathbf{n = 5 0})\end{array}$ & $\begin{array}{c}\text { P VALUE } \\
\text { GOUP II } \\
(\mathbf{n}=\mathbf{5 0})\end{array}$ & \\
\hline EXCELLENT & $41(82 \%)$ & $48(96 \%)$ & 0.0001 \\
\hline GOOD & $9(18 \%)$ & $2(4 \%)$ & 0.0001 \\
\hline FAIR & 0 & 0 & 0 \\
\hline POOR & 0 & 0 & 0 \\
\hline
\end{tabular}


Baseline mean heart rate was $82.45 \pm 8$ and $80.94 \pm 8.17$ per min in group I and group II respectively (p value=0.37). Slight increase in mean heart rate was observed in both groups after the induction. Tracheal intubation caused further increase in mean heart rate in both groups compared with baseline and post induction values. At no time during the study period, significant difference was observed between both the groups $(\mathrm{p}>0.05)$. (Graph 1$)$

Baseline mean blood pressure in group I was $92 \pm 2.13 \mathrm{mmHg}$ and group II was $94 \pm 4.91 \mathrm{mmHg}$ (p value 0.41 ). Decrease in MBP was observed after induction in both groups. At intubation there was an increase in these parameters. A gradual reduction in MBP was observed at 15 minutes after intubation. At no time during the study period, there was a significant difference between the groups $(\mathrm{p}>0.05)$. (Graph-2)

Graph 1:- Mean heart rate (bpm) at various time intervals

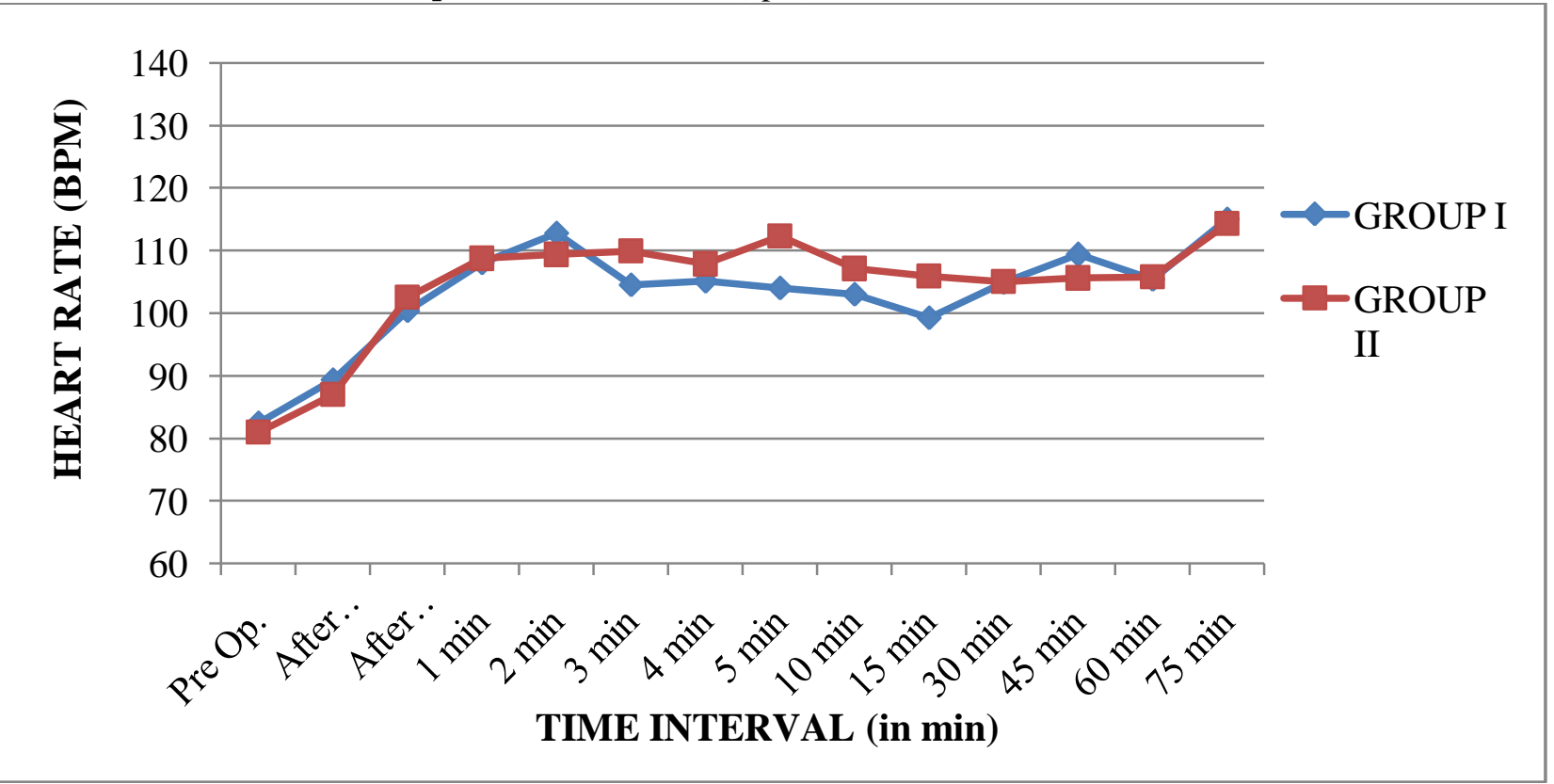

Graph 2:- Mean blood pressure (mmhg) at various time intervals

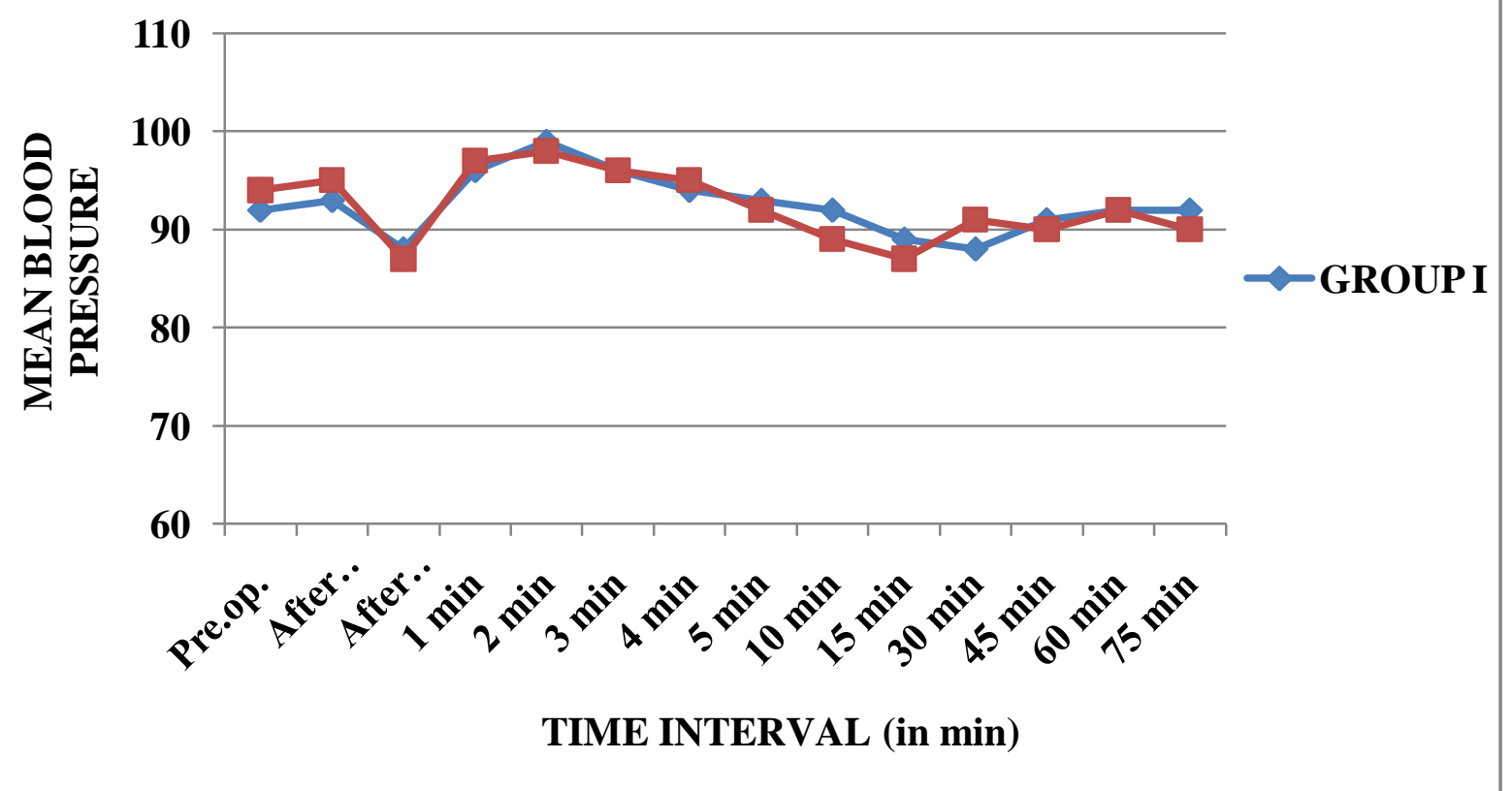




\section{Discussion:-}

The aim of our study was to compare the effects on intubation conditions and haemodynamic response for rapid sequence intubation (RSI) of the two well proven but different anaesthetic induction agents, etomidate and thiopentone sodium, with a rapid acting neuromuscular blocking agent rocuronium in patients undergoing caesarean section.

One of the use of muscle relaxant is to provide conditions necessary for easy and atraumatic intubation.

Rocuronium is a low potency intermediate acting derivative of vecuronium with shorter onset time than the other non depolarizers. It is also devoid of cardiovascular side effects and does not cause histamine release.

In the present study we found that that clinically acceptable intubating conditions were formed in both group I \& group II; excellent intubating conditions were rated in 82\% (41/50) \& 96\% (48/50) and good in 18\% (9/50) and 4\%, (2/50) respectively. Similar results were found in the studies conducted by Cooper R.et al (1992) ${ }^{4}$ and Barve M. et al (2002) $)^{3}$.

There was no significant change in heart rate, mean systolic blood pressure, diastolic blood pressure and mean blood pressure after the administration of the muscle relaxant in either of the groups in the study. The studies conducted by Cooper R. et al (1992) ${ }^{4}$, Barve M.et al (2002) ${ }^{3}$ and Gupta S.et al (2010) ${ }^{8}$ shows similar cardiovascular effects. In these patients rocuronium can be used safely as it does not cause bradycardia rather, it causes slight tachycardia which is not significant clinically. As there is no significant change in heart rate and mean blood pressure with rocuronium, it is the agent of choice in ASA PS I \& II patients undergoing caesarean section cases.

\section{Conclusion:-}

We concluded that both the induction agents; Etomidate \& Thiopentone sodium in combination with Rocuronium were comparable in terms of intubating conditions \& haemodynamic response. Thus it could be concluded that either of them could be used for rapid sequence intubation in pregnant patients undergoing lower segment Caeserean section (LSCS).

\section{References:-}

1. Belekar V.R., Khamankar S. Rocuronium for tracheal intubation in patients undergoing emergency surgery. International Journal of Pharmacological Research. 2013; 3(2): 18-22.

2. Baraka A.S., Sahar S.S., Boutros A.A. Thiopental-Rocuronium Versus Ketamine-Rocuronium for RapidSequence Intubation in Parturients Undergoing Cesarean Section. Anaesthesia Analgesia. 1997; 84: 1140-47.

3. Barve M., Sharma R. Comparison of intubating conditions and time course of action of rocuronium bromide and succinylcholine in paediatric patients. Indian Journal of anesthesiology. 2002; 46 (6): 465- 68.

4. Cooper R., Mirakhur R.K., Clarke R.S.J., Boules Z. Comparison of intubating conditions after administration of ORG 9426 (rocuronium) and suxamethonium. British Journal of Anaesthesia. 1992; 69: 269-73.

5. Dobson A.P., McCluskey A., Meakin G., Baker RD. Effective time to satisfactory intubation conditions after administration of rocuronium in adults Comparison of propofol and thiopentone for rapid sequence induction of anaesthesia. Anaesthesia, 1999; 54: 172-97.

6. El-Orbany M.I., Joseph N.J., Salem M.R. Tracheal intubating conditions and apnoea time after small-dose succinylcholine are not modified by the choice of induction agent. British Journal of Anaesthesia. 2005; 95 (5): 710-14.

7. Fuchs-Buder T., Sparr H.J., Ziegenfub T. Thiopentone or Etomidate for rapid sequence induction with rocuronium. British Journal of Anaesthesia. 1998; 80: 504-06.

8. Gupta S., Kirubahar R. A comparative study of intubating conditions of rocuronium bromide and suxamethonium in adult patients. Anesth Essays Res. Jan-Jun 2010; 4(1): 5-9.

9. Khalid S.A., Ali S.H.., Aftab S., Kazmi W.H. Two Forgotten Agents; Etomidate versus Thiopental Sodium with Rocuronium for rapid sequence induction. Annals of Abbasi Shaheed Hospital \& Karachi Medical \& Dental College. 2014; 19(2): 79-84.

10. Khatri C., Khatri K., Jain V. Comparison of Onset, Duration of Action and Intubating Conditions of Three Dosages $0.3 \mathrm{mg} / \mathrm{kg}, 0.6 \mathrm{mg} / \mathrm{kg}, 0.9 \mathrm{mg} / \mathrm{kg}$ of Rocuronium Bromide. International Journal of Science and Research. May 2016; 5(5): 729-33. 
11. Khurshid H., Khawer M., Shabir A.W. A comparative study of intubating conditions using succinylcholine and two doses of rocuronium. International Journal of Advanced Research. 2015; 3 (5): 1152-59.

12. Kirkegaard N.H., Caldwell J.E., Berry P.D. Rapid Tracheal Intubation with Rocuroniurn: A Probability Approach to Determining Dose. Anesthesiology. 1999; 91:131-36.

13. Kwon M.A., Song J., Ju-Ri Kim. "Tracheal intubation with rocuronium using a "modified timing principle" Korean Journal of Anesthesiology. Mar 2013; 64(3): 218-22

14. Lapisatepun W., Churnjongkolkul W., Nontawasee K., Punjasawadwong K. Rapid sequence induction with rocuronium at $0.45 \mathrm{mg} / \mathrm{kg}$ : Comparison of intubating conditions between ketamine and propofol induction. Chiang Mai Med J 2010; 49(1):11-17.

15. McCourt K.C., Salmela L., Mirakhur R.K., Carroll M., Ma“ kinen M.T., Kansanaho M. et al. Comparison of rocuronium and suxamethonium for used during rapid sequence induction of anaesthesia. Anaesthesia. 1998; 53: 867-71.

16. Miller R.D., Vuyk J., Sisten E., Rockers M. Miller's Anesthesia: Intravenous anaesthesia. $7^{\text {th }}$ ed. (26): 723-29.

17. Miranda L. C. G. de., Barrucand L., José Costa T.S.A., Verçosa N. A Comparative Study between One and Two Effective Doses (ED95) of Rocuronium for Tracheal Intubation. Revista Brasileira de Anestesiologia May-Jun 2008; 58(3): 202-09.

18. Piya R. Comparison of intubating conditions during rapid tracheal intubation between Rocuronium and combination of Rocuronium with Vecuronium. JGPEMN: Jan-June 2014; 3(1): 19-27.

19. Rohsbach C.B., Wirth S.O., Lenz K., Prieb H.J. Survey on the current management of rapid sequence induction in Germany: Minerva Anestesiologica. July 2013; 79(7): 716-22.

20. Sathe V., Sivashankar K.R., Sharma R.C., Gangawane A.K. Comparison of intubating conditions with rocuronium and vecuronium at specific times judged by clinical criteria. Neuroscience Research. 2010; 1(1): 09-25.

21. Shahnawaz M. Md., Shahjahan B., and Siddiqui S.S. Evaluation of intubating conditions after rocuronium bromide in adults induced with propofol or thiopentone sodium. Journal of Anaesthesiology Clinical Pharmacology. Apr-Jun 2011; 27(2): 215-19.

22. Shukla A., Dubey K.P., Sharma M.S.N. Comparative evaluation of haemodynamic effects and intubating conditions after the administration of ORG9426 (Rocuronium) and succinylcholine e. Indian Journal of Anaesthesiology. 2004; 48(6): 476-79.

23. Singh A., Bhatia P.K., Tulsiani K.L. Comparison of onset time, duration of action and intubating conditions achieved with suxamethonium and rocuronium. Indian journal of Anaesthesiology. 2004; 48(2): 129- 33.

24. Skinner H.J., Biswas A., Mahajan R.P. Evaluation of intubating conditions with rocuronium and either propofol or Etomidate for rapid sequence induction. Anaesthesia. 1998; 53: 702-10.

25. Mathias S, Wolfgang U, Wolfgang S., Siegemund M.M, Stephan C. Rocuronium Versus Succinylcholine for Rapid Sequence Induction of Anesthesia and Endotracheal Intubation: A Prospective, Randomized Trial in Emergent Cases. Anesthesia \& Analgesia: Nov 2005; 101(5): 1356-61.

26. Somani M., Sharma P, Sachdev S, Mathur V, Chaturvedi S. A Comparative Study between Vecuronium and Rocuronium for Intubating Condition and Hemodynamic Changes. Journal of Dental and Medical Sciences. Jun 2014; 13(6): 33-9.

27. Sparr H.J., Giesinger S, Ulmer H., Hollenstein-Zacke M., Luger T.J. Influence of induction technique on intubating conditions after rocuronium in adults: comparison with rapid-sequence induction using thiopentone and suxamethonium. British Journal of Anaesthesia. 1996; 77: 339-42.

28. Stoelting R.K, Rathmell J.P., Roscow C.E. Stoelting's Pharmacology and physiology in anaesthestic practice. Intravenous sedation and hypnotics. $3^{\text {rd }}$ ed. (5): 127-30.

29. Yeoh S.B., Sng B.L, Alex S.T.H. Anaesthesia for lower segment caesarean section: Changing perspectives. Indian Journal of Anaesthesia. Sep-Oct 2010; 54(5): 409-14. 